\title{
COOPERATIVE LEARNING ISSUES IN ELEMENTARY EDUCATION: A LITHUANIAN CASE STUDY
}

\author{
DAIVA JAKAVONYTĖ-STAŠKUVIENĖ \\ Vytautas Magnus University Education Academy \\ T. Ševčenkos g. 31, LT- 03111 Vilnius, Lithuania \\ E-mail address: daiva.jakavonyte-staskuviene@vdu.lt \\ ORCID: https://orcid.org/0000-0002-8080-8848 \\ AUŠRA ŽEMGULIENĖ \\ Vilnius University Institute of Educational Sciences \\ Universiteto g. 9, LT-01513, Vilnius, Lithuania \\ E-mail address: ausra.zemguliene@fsf.vu.lt \\ ORCID: https://orcid.org/0000-0001-8622-6323 \\ EMILIJA SAKADOLSKIS \\ Vilnius University Institute of Educational Sciences \\ Universiteto g. 9, LT-01513, Vilnius, Lithuania \\ E-mail address: emilija.sakadolskis@fsf.vu.lt \\ ORCID: https://orcid.org/0000-0003-0568-8003
}

\begin{abstract}
Aim. Cooperative learning (CL) is a widely recognised pedagogical practice which involves students working together to achieve common goals that they could not complete individually. Johnson and Johnson are among the main theorists behind the movement. In 1994 they announced five elements essential for the successful incorporation of $\mathrm{CL}$ in the classroom: (a) positive interdependence; (b) face-to-face promotive interaction; (c) individual and group accountability; (d) interpersonal and small group social skills; (e) group processing. In this study we seek to understand how primary school teachers implement cooperative learning and include the above-mentioned aspects in their classes.

Methods. The qualitative case study was conducted at a primary school in Vilnius, Lithuania. Two lessons were recorded, transcribed, and analysed to gather evidence concerning variables that mediate cooperative learning. The teachers planned the lessons together, using the principles that are outlined in a professional development method called Japanese lesson study. The study involved two teachers and $40(20+20$ pupils in two classes) fourth graders. Also, interviews were conducted with the teachers and three pupils from each class.
\end{abstract}


Results and conclusion. The forms of cooperative learning observed in the classrooms were markedly different, even though the lesson plans were almost identical. In Lesson 1 the teacher paid more attention to interdependence, interaction, and reflection. Consequently, students mentioned cooperation, assistance, and specifics of group work more frequently. In Lesson 2, there was more traditional group work than CL schemes, and less interdependence, interaction, and reflection. The five essential elements were unequally represented in the lessons, highlighting the varied understanding of CL. 'In situ' research revealed which elements of cooperative learning need to be stressed in teacher pre-service and in-service settings. The study also deepened the understanding of which aspects are more difficult to implement, or which have made significant inroads into classroom practice.

Originality. Situational research involving both CL and Japanese Lesson Study techniques provide valuable insights into the professional development of teachers who aim to improve their classroom practice.

Key words: cooperative learning, group processing, social interdependence theory, Japanese lesson study

Tn 2018 The Organisation for Economic Cooperation and Development published a document outlining the competencies that pupils need to shape their own lives and to contribute to the lives of others. To achieve this goal, the organisation launched The Future of Education and Skills 2030 project (OECD, 2018). The aim of the project is to help countries find answers to two questions: (a) What knowledge, skills, attitudes and values will today's students need to thrive and shape their world? (b) How can instructional systems develop these knowledge, skills, attitudes, and values effectively?' (p. 2).

Cooperation is only one of the skills emphasised in the OECD project. The document highlights the skills that are and will continue to be essential for problem solving: 'Learning to [...] work with others with different perspectives, [...] and identify multiple solutions to big problems will be essential in the coming years. Education [...] needs to equip students with the skills they need to become active, responsible, and engaged citizens' (OECD, 2018, p. 4). The document also stresses that this can be better achieved through collaborative rather than individual efforts: 'Increasingly, innovation springs not from individuals thinking and working alone, but through cooperation and collaboration with others to draw on existing knowledge to create new knowledge. The constructs that underpin the competency include adaptability, creativity, curiosity, and open-mindedness' (OECD, 2018, p. 5).

Inspired by these OECD initiatives, innovative cooperative practices were chosen as the focus for a three-year international strategic partnership Erasmus + project titled 'Inclusive cooperation devices' (Dispositifs Inclusifs de Coopération), that involves 8 countries: France, the Netherlands, Italy, Spain, Hungary, Romania, Switzerland, and Lithuania (DICO+, 2019). Through documented classroom experiments the consortium will share practices and compare current approaches that encompass schooling in Northern, Southern, Central, and Eastern Europe. This will enable the development of a public platform for sharing resources, as 
well as ideas and tools for pre-service and in-service teacher education. In this article, we present Phases I and II of the research project that took place in Lithuania before the Corona virus pandemic forced a temporary break in the project.

\section{WHY COOPERATIVE LEARNING?}

Cooperative learning is a recognised pedagogical practice that traces its beginnings to the 1930s and 1940s, when social theorists, philosophers, and psychologists found that people who work together are more effective and efficient in attaining successful outcomes than those who work independently to achieve the same goals (May \& Doob, 1937; Kohn, 1992; Gilles \& Adrian, 2003). Research on instruction that employs small-group learning has repeatedly shown that secondary level students outperform those working in large group settings in the areas of knowledge development, thinking skills, social skills, and satisfaction (Davidson \& Major, 2014).

Many terms have been used for group learning, i.e., small-group learning, collaborative learning, cooperative learning, problem-based learning, teambased learning, peer instruction, peer tutoring, team learning, and others. It should be noted that many educators make the mistake of conflating these terms despite similarities, there are some key differences. Most commonly, collaborative and cooperative learning are used interchangeably. Collaborative learning is based on consensus building among group members. Students work to produce common knowledge, not necessarily in collaboration (interdependently). Cooperative learning is understood as a classroom technique: a set of processes which help pupils interact to accomplish a specific goal. It is more directive than collaborative, and it is more closely controlled by the teacher to maximise learning outcomes (Panitz, 1999). 'In a collaborative project [...] students could divide up the task and assemble the individual parts in order to accomplish the common goal. In contrast, cooperative learning would require some cooperation in which all members would be held accountable to increase their knowledge of the individual parts' (Davidson \& Major, 2014, p. 21-22). Cooperative learning is the specific approach examined in this research project, although we also encountered elements of collaborative learning, peer tutoring, and other forms of group work.

It should also be noted that many Lithuanian teachers consider any kind of group work to be cooperative. Traditionally, when students are asked to work in a group, the tasks are undertaken by those who are higher achievers or show more initiative, allowing other members to passively observe and concur. Therefore, teachers have not been very enthusiastic in their reactions to cooperative learning (or about what they assumed to be CL), since they were not aware of the deliberate methods and structures that have been devised to overcome the shortcomings of traditional 'group work'.

Since cooperative learning has become such a well-known and widespread practice, we will not present the entire methodology in this article. It should be 
noted that cooperative learning theory, methods, and structures have developed in varying yet complementary directions through the work of several theorists and research centres. Most prominent are the contributions of David W. Johnson and Roger T. Johnson of the Cooperative Learning Center at the University of Minnesota. According to Johnson and Johnson (2005, 2019), cooperative learning is based on two theories: Structure-Process-Outcome theory and Social Interdependence theory. Also prominent in the development of cooperative learning theory are Robert E. Slavin at the Center for Research and Reform in Education at Johns Hopkins University, Spencer Kagan at the University of California, and others. Their works are readily available to those interested in learning more about the practice (Johnson \& Johnson, 1975, 1994; Johnson, Johnson, \& Holubec, 1994; Slavin, 1994, 1995; Kagan, 1994; Kagan \& Kagan, 2009).

Confidence in the method has been supported by numerous research studies and meta-analyses of the effects of cooperative, competitive, and individualistic goal structures on student achievement in the 1980s. Follow-up studies in the 1990s and the beginning of this century examined the effects of cooperative, competitive, and individualistic learning on such variables as: increased attendance, achievement, time on task, interpersonal relationships, mutual liking, social support, self-esteem, perspective taking, learning together, motivation, and the increase in a variety of thinking strategies, resulting in strong effect sizes in favour of cooperative learning. Clearly, we have a solid body of evidence that the pedagogical practice of cooperative learning has a profound positive effect on student learning and socialisation (Johnson \& Johnson, 1975; Augustine, Gruber, \& Hanson, 1989-1990; Slavin, 1990; Gillies, 2016).

Johnson and Johnson indicated five elements essential for the successful incorporation of cooperative learning in the classroom (Johnson \& Johnson, 1990, 1994, 1999, 2003, 2005; 2008a; Gillies, 2004, 2008; Buchs, 2017; SERC, 2020). These five elements are the themes for which we looked when making decisions how to code the data acquired during our research process:

- positive interdependence - pupils understand that they must fully participate and are linked with their classmates, and that they cannot succeed unless all of them succeed. Each group member has a task, role, or responsibility, crucial for both their own learning and that of their group, which cannot be completed by any other group member.

- face-to-face promotive interaction - pupils encourage and facilitate each other's efforts to achieve the assigned task. They explain to one another what they are learning and help each other understand and complete assignments. Important cognitive activities and interpersonal dynamics occur only when pupils promote the learning of other team members. It is then that they become committed to one another and their common goals.

- individual and group accountability - pupils understand that each of them is responsible for contributing a fair share of the group's work. Each student must demonstrate mastery of the studied content, not relying on other members to do the work. 
- interpersonal and small group social skills - this includes purposefully teaching students about communication, leadership, trust building, decision making, friendship development, and conflict management.

- group processing - the group reflects on how well the group members are working cooperatively and how it would be possible to improve. They make decisions about which actions should continue or change to improve the effectiveness of group processes.

\section{RESEARCH QUESTIONS, OBJECTIVES, AND METHODS}

This research is a case study, allowing the examination of real situations and experiences (Stake, 2006; Verhoeven, 2010). This method is particularly useful, when the researchers have limited control of events, but would like the answers to "how" and "why" questions (Yin, 2018). We were interested in how two fourth grade teachers involved in the project employed cooperative learning activities. We analysed certain behaviours, how they made and implemented decisions, as well as the results of the observed lessons. The goal is to augment available research and resources on cooperative learning practices in primary school settings, recognising that there is no single correct educational practice. The research objectives:

- To record evidence of the five variables that mediate cooperative learning effectiveness (i.e., positive interdependence, face-to-face promotive interaction, individual and group accountability, interpersonal and small group social skills, group processing),

- To analyse how pupils view communication and cooperation: (i.e., what added value they can discern; how they reflect on responsibility; what learning skills they seek; what they believe hinders good communication and cooperation),

- To analyse teachers' reflections after the lesson and the lesson revision process regarding areas of improvement (both achieved and sought).

During the analysis of lesson video recordings, the previously mentioned five essential elements of cooperative learning were documented via observation forms. This allowed us to study how the implementation of cooperative learning practices varied when delivered by different teachers, even when the lesson plan is almost the same (Altet, Bru, \& Blanchard-Laville, 2012). Additional data were gathered through partially structured interviews, with the teachers and three pupils from one team in each class.

The analysis of video data is a complex process during which we seek to understand complicated practices by blending psychological and didactic elements, the various perspectives of teachers and pupils, instructional contexts, methods, and achievements (Altet, 2017). The pupil activity that is captured on film is deconstructed and analysed. Only that data, which are relevant, reliable, and discernible for substantiating a certain activity are chosen for analysis (Durand, Ria, \& Veyrunes, 2010). This allowed us to examine the quality 
of learning and group processes, social involvement, and the added value of cooperation. We were able to see when the work was productive, what caused problems, which pupil actions demonstrated involvement or passivity. The subsequent interviews allowed us to examine whether the teacher and pupils thought that they achieved the desired results, what went well, and what they believed should change.

The process of learning with others is multi-faceted, involving variables such as class climate (proper attitudes, appropriate content, purposive assignments, time management); a foundation for learning and cognition (allowing the increase of knowledge); and cooperative activities (necessary for cohesive teamwork). These three components are related to the social-cognitive aspects of a teacher's work (Altet, 2009a, 2009b; Clanet, 2009). When analysing pupil activities in cooperative learning structures, the factors and undefined variables provided by the teacher are also very important (Johnson \& Johnson, 2008a; Gillies, 2004, 2008; Hattie, 2009; Bressaux, 2012; Talbot \& Bru, 2007). This includes the teacher's input in providing a motivating classroom climate. The teacher acquaints pupils with new models of thinking, problem solving strategies, initiates constructive discussion and promotes respectful behaviour. Cooperative activities require time to consult, listen, and understand the ideas of each group member. Formative evaluations are particularly important so that the teacher can provide constructive suggestions. In view of this, the conditions for cooperative learning such as class climate, the teacher's role, and mediation were also chosen as themes, in addition to the above-mentioned expressions of cooperative skills, allowing for a more multi-layered analysis (Stake, 2006).

\section{PARTICIPANTS, DATA COLLECTION AND ANALYSIS SCHEME}

The research was conducted at a primary school in Lithuania's capital Vilnius during the 2019-2020 school year. Preceding the cooperative learning target lessons, the project participants and their colleagues from the school received in-service professional development regarding the principles and structures of cooperative learning and how this technique differed from traditional group work. The participants also partook in workshops on Japanese lesson study (Doig \& Groves, 2011), which was the method used by all participants of the $\mathrm{DICO}+$ project to improve the lessons as they were repeated with different classes. It should be noted that the lesson study format recommends that a lesson be repeated in three different classrooms. However, school closures due to the COVID-19 pandemic allowed for only two experiments, which limit the scope of this study.

Eight teachers taught specifically planned lessons in grades one through four. Most parents granted permission to film the classes and use the material for research purposes. Only a few parents refused, and their children were not filmed during the lesson. In this article we present findings from lessons conducted by two fourth grade teachers. Each class consisted of 20 pupils. 
The cooperative learning groups were heterogeneous in terms of gender, aptitude, and achievement level. The entire class was filmed, but one team was chosen for more intense observation. We also arranged to include a pupil with learning difficulties in the team that was being observed. The team in the first lesson consisted of five pupils - two girls and three boys. The team in the second lesson consisted of four students - one girl and three boys. After each lesson, the members of this target team and their teacher were interviewed. Written supplementary material about the teachers was gathered from the school's assistant director. The collected video data from the lessons and the interviews were transcribed; relevant episodes were chosen and analysed together with the information from the observation forms.

The qualitative data analysis focused on the five essential elements of cooperative learning. Visual materials and interview statements were matched to the five themes. The reasoning behind this analysis of the data is presented in Table 1. The context and themes are described for each lesson. Themes are investigated with the aid of sub-themes making cross-comparisons of similarities and differences (Creswell, 2007). The results are summarised, and conclusions are made. All figures and tables illustrating data excerpts and analysis themes are generated by the authors of this article.

Table 1

The data analysis scheme for research on cooperative learning

\begin{tabular}{|c|c|c|c|c|c|c|}
\hline \multicolumn{7}{|c|}{ Case contexts } \\
\hline \multicolumn{2}{|r|}{ Case 1} & \multicolumn{5}{|c|}{ Case 2} \\
\hline \multicolumn{7}{|c|}{ Case accounts } \\
\hline \multirow{5}{*}{ 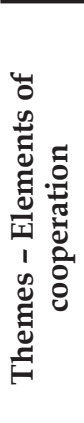 } & Subthemes & & & ata sources & & \multirow{5}{*}{ 今) } \\
\hline & & Video & $\begin{array}{c}\text { Group } \\
\text { observation } \\
\text { form }\end{array}$ & $\begin{array}{c}\text { Interviews } \\
\text { with } \\
\text { pupils }\end{array}$ & $\begin{array}{c}\text { Interview } \\
\text { with } \\
\text { teacher }\end{array}$ & \\
\hline & Class climate & $X$ & & & $X$ & \\
\hline & Teacher role & $X$ & & & $X$ & \\
\hline & Group work & $X$ & $X$ & $X$ & $X$ & \\
\hline
\end{tabular}

Data were examined by two researchers. Teacher A conducted Lesson 1 , and Teacher B conducted Lesson 2. Pupil aptitude and achievement levels (for the three children in each class that were chosen to be observed more closely and interviewed) are indicated as: P-1(lower), P-2 (average), and P-3 (advanced). 


\section{RESEARCH RESULTS}

\section{Case contexts}

Lesson 1.

Teacher A has been teaching for 39 years and has been certified as an 'expert teacher' - the highest ranking in a five-tier system of career stages. According to the assistant director, 'She is guided by the contemporary paradigm of learning. She often organises the learning process in pairs or groups, and pupils are encouraged to interact, cooperate, offer ideas, raise questions, and discuss. Friendly relationships based on trust are being created in the class. The teacher confidently tries out a variety of innovations, is constantly honing her work skills and is capable of reflecting on her professional activities.'

The teacher chose the theme of Lithuania's eminent historical personalities. During the lesson, the pupils were to review and summarise what they already knew about famous Lithuanian historical figures. They could use textbooks and information sheets about the figures and their importance. There were four groups of five pupils each. It was noted that the introductory part of the lesson was too long, resulting in a time crunch. The pupils worked quickly, they completed the tasks and discussed how well they worked together and cooperated; however, there was not enough time to generalise the reflections.

The introductory part of the lesson was devoted to encouraging cooperative learning. Syllables were written on cards to be arranged to spell out the topic of the lesson. Cooperation was certainly emphasised, but the task was too easy and had little epistemic value.

The main part of the lesson included four tasks.

Task 1 (5 minutes). Each group received envelopes containing coloured circles of paper with clues about a certain person, as well as triangles with the names of the personalities. The pupils were to paste the triangles on the matching circles and to add a fact about that person. These were then pasted on a poster and presented to the entire class. Group processing focused on the following criteria: Help (I did it myself; I received help; I helped others); Information (I knew that; I looked for information); and Participation (I participated; my classmates did the work).

Task 2 (10 minutes). Each group received envelopes containing the names of two personalities. They also received their photos. The pupils were to prepare presentations about these persons and had to include at least three facts regarding why they were famous, what they accomplished, and what they created. The group had to decide their place of birth and paste the photo on a map in the appropriate place. After their presentation to the entire class, they were to answer their classmates' questions. They could use textbooks, other books, their own homework, and photos. The pupils were directed to discuss and decide which three facts to include in the poster and where to paste the photos. The teacher stressed both content and cooperative work. Upon completion, each group announced how well they worked together, what difficulties they encountered and how they resolved them. 
Task 3 ( 5 minutes). A timeline of historical periods from the $15^{\text {th }}$ to the $21^{\text {st }}$ centuries was taped to the board. Each group received three circles with the names and photos of personalities. Pupils had to decide in which century to paste their circles.

The conclusion of the lesson was devoted to processing. The pupils had to write statements on 'sticky notes' to be pasted in appropriate 'clouds' on the board that included the following questions: What did I learn that was new? What else would I like to learn? What was interesting? What did I not like and why? The children completed the task, but there was not enough time for discussion.

\section{Lesson 2}

Teacher B has taught for 44 years and is certified as a 'senior teacher' - the third career stage in the five-tier system. The assistant director described her as 'calm, sensitive, empathic. She is able to create friendly, supportive interrelationship. She usually employs traditional models of teaching that include discussion, explanation, narrative, while working in pairs or groups is less frequent. The teacher has experience working with special needs students and can adapt content to their needs and capabilities.'

After Lesson 1 both teachers evaluated it and discussed possible improvements. They decided that the pace of the lesson was too fast, yet there was not enough time for discussion at the end. Therefore, they reduced the scope of the second task. There were five groups of four pupils each. The lesson structure and tasks remained the same, but there was a smaller number of historical figures.

Before the lesson, the teacher distributed self-assessment forms, which were to be coloured in green ('well done'), yellow ('not everything was accomplished') or red ('it was not done'). She instructed the pupils to not look at the sheets until they had completed the first task, and she also told them not to use red.

She reviewed the names of the ethnographic regions of Lithuania. Pupils were not allowed to use additional resources, leaving us with the impression that she did not fully understand the essence of cooperative learning. During the activities, the teacher received little information about pupils' learning, needs or achievements. The lesson seemed staged and imitative.

The introductory part of the lesson was shortened to allow more time for the main lesson. The main part of the lesson contained somewhat altered tasks of Lesson 1.

Task 1 (10 minutes). This part was not changed. Discussion about this task regarding what was most difficult was conducted with the teacher standing in a frontal position. Thus, processing focused on information rather than on group work skills. The teacher asked who worked well in the groups and all hands went up.

Task 2 was reduced. The groups were asked to present not two but one personality. The photos were posted on the map immediately after the presentations. This left more time for the historical timeline task. 
Task 3 was also reduced. Each group received two historical personalities instead of three to post on the timeline.

The conclusion of the lesson plan was not changed, anticipating sufficient time for processing.

The pace of Lesson 2 was slower, when compared with Lesson 1. Classmates posed less questions to the groups presenting their posters, and pupils were not as proficient at getting involved and actively cooperating. Despite positive changes and optimisation of content, the time management issue recurred in Lesson 2: pupils wrote reflections on sticky notes, posted them on the board, but the lesson ended before the entire class could discuss what they had written.

\section{Case accounts}

In summarising the findings of numerous research studies regarding suitable prerequisites for cooperative learning, Johnson and Johnson (2008b) present the following factors: a well-thought-out lesson structure, classroom climate, group formation, tasks and teaching materials suitable for knowledge growth and fostering of cooperation, as well as stimulating support from the teacher. One aspect of our analysis focused on how the two teachers fostered cooperative skills during their lessons. Using various data sources, we looked at how the work was organised, whether pupils understood, supported, and encouraged each other's efforts to reach goals, and whether the teacher facilitated these undertakings.

Classroom setting. The structure of Teacher A's lesson plan was thoughtout; it included an introduction, main body, and a conclusion. The classroom was prepared for working in groups: desks were positioned, there was space for presentations. The groups were heterogeneous to include pupils of varied aptitudes and achievement levels. Teacher B did not change the structure of the lesson, which consisted of the same parts as Lesson 1. The classroom was also prepared for group work, and the principle of heterogeneity was maintained.

Lesson content. Teacher A presented meaningful tasks suitable for group work. Pupils received appropriate handouts and could use books and homework assignments about eminent Lithuanian personalities. Teacher B intentionally amended the content, reduced the scope of the tasks and prepared handouts. However, in both cases the knowledge to be acquired was factbased, not allowing for essential questions that could encourage divergent thinking. It is entirely possible that the teachers were so focused on creating cooperative learning opportunities for the purposes of the DICO+ project that more rigorous content was overlooked. There was little attention paid to critical thinking or problem-solving tasks.

Time allocation. Teacher A did not foresee the amount of time needed for all the components of the lesson. There was a prolonged introduction, and time was spent on revisiting topics from previous lessons. Although pupils were involved and actively answered questions, the amount of time devoted to other matters before introduction of the new material was too long. Later 
the tempo had to be increased and there was not enough time for the timeline activity. Group processing did not occur. Teacher B also did not fit into the allotted time, despite altering the amount of material to be covered, possibly because the pupils in this class worked at a slower pace.

The teacher's role. Fostering cooperative skills involves more than ensuring an appropriate classroom setting and curriculum. The teacher's active role is paramount. They must observe, stimulate group learning, summarise achievements, provide support and feedback (Johnson \& Johnson, 2008b). Teacher A clearly encourages a culture of cooperation, constantly stressing the benefits of collective work, cultured interaction and constructive problem solving in her communications to the class. At the beginning of the class, she reminds pupils to discuss various possibilities before making their decisions. She monitored the activities and group work, raised pointed questions, asked for corrections, and gave advice. The teacher also made sure the pupils had thought about why they were learning the material. The students responded: 'To know more,' 'To learn about Lithuania's past,' 'So that we could tell others about these Lithuanian personalities; to tell people from other nations about Lithuanian personalities, so we could tell our children and grandchildren.' The pupils did not review the rules of cooperation and it became clear that they had done this before and already knew the rules. The teacher did not let them get away with easy answers. When the pupils stated that they worked 'splendidly,' the teacher asked them for evidence. They responded by saying that they helped each other and did not get into arguments. Another group said that they worked very well, but when confronted with the question of how they divided up the tasks, the children admitted that they did not do so well after all. Unfortunately, they blamed P-1 for not doing their part. Two groups admitted that they argued, but teacher A reminded them that truth is born from argument, that you can reach consensus, and that we must adhere to our agreements. She also devoted time to written and oral processing of group work and pupils were open about their strengths and shortcomings, letting us believe that they did this regularly. During the interview teacher A was pleased that 'they helped each other; the help was timely and useful; they almost did not need my help - only minimally.'

Teacher B was rather nervous and spent a lot of time refining the content, but these changes were insufficient for fostering cooperation skills. She worried whether her pupils would finish in time. There were no explanations or discussion about the specifics of group work at the beginning of the lesson, and the students were immediately given a task. This might not have been an issue in teacher A's class, but it was apparent that teacher B's class had little experience with group work and going over the principles of cooperation would have been beneficial. It was clear that teacher B perceived her role in terms of content much more than in relation to teaching cooperative skills. Although the pupils filled out the self-evaluation forms after each task, the teacher encouraged them to get through them quickly and did not follow up with analysis. Questioning was frontal and did not create opportunities for pupils to under- 
stand the benefits of working collectively. When asked about the difficulties which they had encountered, the pupils only reported those that had to do with finding sources and writing them up. Others claimed that everything was very easy. Nobody mentioned any aspects of group work. Teacher B also had little to say about group processes, simply stating that 'it took me two weeks to prepare just for this.' When asked about possible improvements, she again focused only on the content.

\section{The five elements of cooperative learning}

\section{Positive interdependence}

Social interdependence theory describes positive interdependence (as opposed to negative dependence, no dependence, or no interaction) as the attainment of goals with the help of others (Johnson \& Johnson, 2003, 2005, 2008b). Most important is the group's understanding that they are linked to one another and that they cannot succeed unless all of them succeed. Naturally, there will be those who struggle and need help, and properly structured cooperative learning helps these students the most. However, high achievers are not negatively affected, but rather they gain opportunities to manage and become 'soft leaders' (Hmelo-Silver, Kati, Nagarajan, \& Chernobilsky, 2007; Gillies, 2008). Also, it should be noted that our description of positive interdependence includes this provision: 'Each group member has a task, role, or responsibility for both their own learning and that of their group, which cannot be completed by any other group member.'

Unfortunately, this element of cooperative learning was virtually nonexistent in these lessons. There was nothing in the structure of the task that precluded the success of a fellow group member, if a classmate did not do their assigned part. There was also nothing in the task that required a student to make sure that the other teammates understood and mastered someone else's contribution. There was little construction of knowledge that required intense deliberation and deep understanding. In that sense, the lesson plans resembled collaborative learning more than cooperative learning. Also, a fellow team member could easily 'pick up the slack' of an inactive pupil by doing a job that was not his own. An example of negative dependence occurred in Lesson 2, when teacher B (who was seen and heard by all) approached P-1 and announced that P-3 had created a summary sheet that P-1 could use during the lesson.

Clearly, this was a failure on our part. As researchers and mentors, we understood the need for providing professional development on cooperative learning for the project teachers, since we realised early on that they inadequately understood the difference between cooperative learning and traditional group work. We stressed the element of face-to-face interaction and interpersonal small group skills at the expense of positive interdependence issues. While we presented various cooperative learning strategies, such as the Kagan Structures (Kagan, 2013) that have been devised to ensure positive interdependence, the time spent during the professional development seminars was evidently insuf- 
ficient. Therefore, we encountered instances of the kind of shortcomings that are usually associated with traditional group work. While we observed excellent examples of children wanting to help each other, these provided good evidence of promotive interaction (as seen in the next section), rather than positive interdependence.

\section{FACE-TO-FACE PROMOTIVE INTERACTION}

In Lesson 1 there were numerous examples of pupils promoting interaction. They encouraged and facilitated each other's efforts and assisted in the completion of assignments. Table 2 presents audio and visual data from the video of the target group. It should be noted that other groups exhibited similar behaviour.

Table 2

Observed promotive interaction during Lesson 1

\begin{tabular}{|l|l|l|}
\hline Episode & Duration & Evidence \\
\hline $\begin{array}{l}\text { Orientation } \\
\text { towards a } \\
\text { result: } \\
\text { working to- } \\
\text { gether; } \\
\text { sharing jobs; } \\
\text { interaction; } \\
\text { body positions; } \\
\text { sharing items } \\
\text { and materials; }\end{array}$ & $\begin{array}{l}\text { Comments } \\
30.13 .30\end{array}$ & -04.19 .40 \\
30.51.07 & $\begin{array}{l}\text { One boy holds the paper, } \\
\text { the other applies the glue. } \\
\text { Two girls paste the pa- } \\
\text { pers on the timeline. P-1 } \\
\text { stands ready to hand the } \\
\text { glue to others as needed. } \\
\text { Group members lean in } \\
\text { towards each other; they } \\
\text { talk, negotiate, and share } \\
\text { materials. } \\
\text { The girls find information } \\
\text { in their sources, while the } \\
\text { boys verify the informa- } \\
\text { tion using their textbooks. } \\
\text { P-1 listens attentively, ris- } \\
\text { ing from his seat, mouth } \\
\text { open. } \\
\text { As pupils confer and } \\
\text { share materials, they are } \\
\text { passed from one to an- } \\
\text { other. } \\
\text { The items (books, writ- } \\
\text { ing implements, glue) are } \\
\text { widely scattered on the } \\
\text { table, giving the impres- } \\
\text { sion that they are commu- } \\
\text { nal property. }\end{array}$ \\
\\
\hline
\end{tabular}




\begin{tabular}{|c|c|c|}
\hline $\begin{array}{l}\text { Encouraging } \\
\text { interaction: } \\
\text { discussion; } \\
\text { encouragement } \\
\text { to speak; } \\
\text { listening; } \\
\text { directing; }\end{array}$ & $\begin{array}{l}12.40 .10- \\
14.05 .43 \\
14.05 .63\end{array}$ & $\begin{array}{l}\text { PM-3 asks P-2, 'How } \\
\text { did you do at your job? } \\
\text { Did you need help? Who } \\
\text { helped you?' } \\
\text { P-3 explains that red } \\
\text { markings mean that 'no- } \\
\text { body helped us.' }\end{array}$ \\
\hline $\begin{array}{l}\text { Leadership } \\
\text { (responsibil- } \\
\text { ity): } \\
\text { job distribu- } \\
\text { tion; } \\
\text { providing help; }\end{array}$ & \begin{tabular}{|l}
$08.12 .20-$ \\
09.40 .60 \\
$10.09 .87-$ \\
10.14 .10 \\
11.13 .27 \\
-11.14 .80
\end{tabular} & $\begin{array}{l}\text { P-3 takes on the 'soft } \\
\text { leader' role and explains } \\
\text { to P-1 what he should be } \\
\text { doing. } \\
\text { P-3 helps P-1 and ex- } \\
\text { plains the task. } \\
\text { P-3 explains and gives P-1 } \\
\text { the summary handout. }\end{array}$ \\
\hline $\begin{array}{l}\text { Leadership } \\
\text { (manage- } \\
\text { ment): } \\
\text { monitoring the } \\
\text { work of others; } \\
\text { directing } \\
\text { towards the } \\
\text { result; } \\
\text { providing op- } \\
\text { portunities for } \\
\text { others; }\end{array}$ & $\begin{array}{l}10.18 .23- \\
10.22 .80 \\
10.26 .57 \\
20.22 .87- \\
21.36 .57\end{array}$ & $\begin{array}{l}\text { P-3 observes the way P-2 } \\
\text { does the task and only } \\
\text { then withdraws from the } \\
\text { others to concentrate on } \\
\text { her own part of the task. } \\
\text { P-3 completes her part } \\
\text { of the task and glues the } \\
\text { triangle onto the circle. } \\
\text { P-3, the group leader, } \\
\text { holds up the poster while } \\
\text { P-2 presents the results of } \\
\text { their work. }\end{array}$ \\
\hline
\end{tabular}

The video material shows pupils who work attentively, actively strive to achieve the common goal, interact, and have close interpersonal ties. They reveal this through their interactions (confer, listen, help each other, jointly present the results, answer questions), through body positions (leaning into each other), their action related to materials (sharing and jointly referring to sources).

Johnson, Johnson and Holubec (1994) devote a great amount of attention to both verbal and nonverbal behaviour during interactions. They encourage teachers to examine what teamwork skills 'look like' and 'sound like.' It is not enough to tell pupils which skills one wants them to use during a lesson. The authors list some of the visual cues that illustrate engagement in good interactive skills. These include smiles, eye contact, thumbs up, a pat on the back, leaning forward, an interested, pleasant expression, open gestures and posture, one person talking with others listening (p. 9:4-9:6). Visual evidence of 
such behaviours can be seen in Figure 1, in which we see other groups of pupils who participated in Lesson 1 (not the one that was selected for analysis). Supporting data from the observation form confirms that these scenes depict positive, open, and respectful interactions among team members.

\section{Figure 1}

Visual examples of face-to-face promotive interaction in Lesson 1

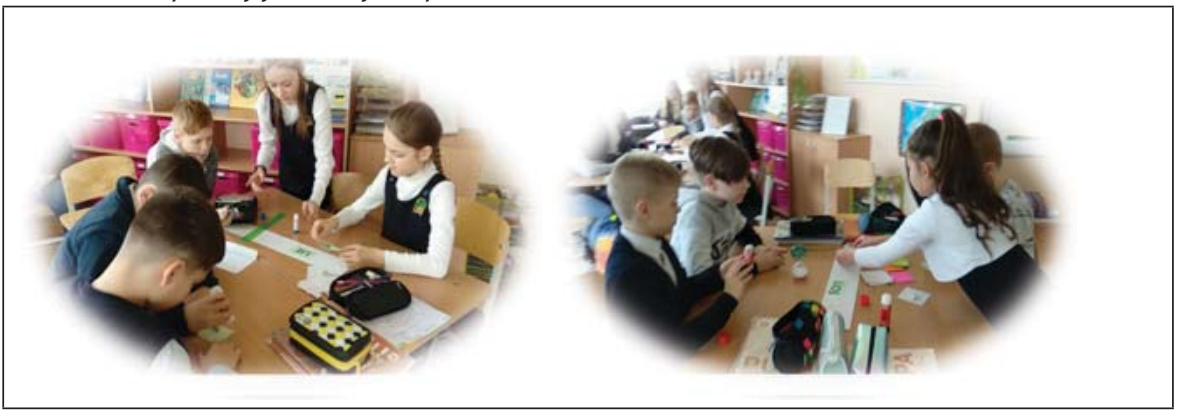

The display of pictures in Figure 2 depicts examples of source and material sharing in Lesson 1 during the search for information needed to create the poster.

\section{Figure 2}

Visual examples of material sharing in Lesson 1

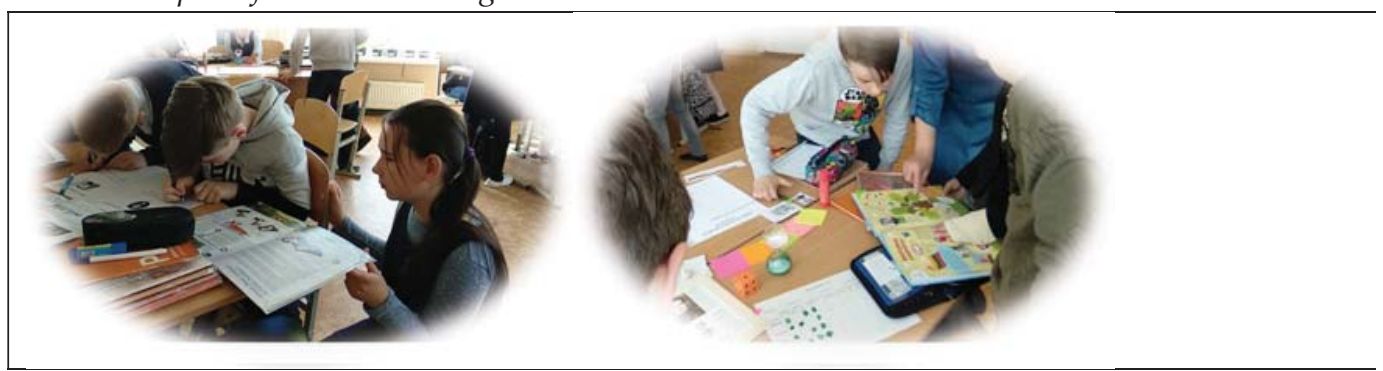

P-3 emerged as the obvious leader who took on the initiative of helping others, especially the lower-achieving P-1. She consolidated everyone's efforts towards the desired result and during the time devoted to reflection at the end of the lesson. She did not upstage the others, but rather listened to the opinions of others, allowed group members' inputs, and let others present the work. She also displayed management skills by monitoring the work of others, directing them towards the desired result, first helping others, and only then turning to her own work.

The information included in the observation forms confirmed the interaction among the group members, especially the close contact between the advanced pupil (P-3) and the struggling pupil (P-1). Interviews with the three 
Table 3

Observed promotive interaction during Lesson 2

\begin{tabular}{|c|c|c|c|}
\hline Episodes & Duration & Evidence & Comments \\
\hline $\begin{array}{l}\text { Orientation } \\
\text { towards a } \\
\text { result: } \\
\text { working to- } \\
\text { gether; } \\
\text { sharing jobs; } \\
\text { interaction; } \\
\text { body positions; } \\
\text { sharing items } \\
\text { and materials }\end{array}$ & $\begin{array}{l}01.11 .23- \\
02.07 .33\end{array}$ & & $\begin{array}{l}\text { During the introductory activity } \\
\text { and during the main tasks the } \\
\text { pupils sit distanced from one } \\
\text { another. } \\
\text { P-2 talks only to the boy next to } \\
\text { him. The two of them complete } \\
\text { their tasks, but they do not speak } \\
\text { to those sitting across them; there } \\
\text { is no cooperation. } \\
\text { P-2 and the boy next to him dis- } \\
\text { tribute the material for task } 1 \text {. } \\
\text { All do their own work, but there } \\
\text { is some pair interaction. P-3 } \\
\text { helps P-1. }\end{array}$ \\
\hline $\begin{array}{l}\text { Encouraging } \\
\text { interaction: } \\
\text { discussion; } \\
\text { encouragement } \\
\text { to speak; } \\
\text { listening; } \\
\text { directing; }\end{array}$ & $\begin{array}{l}01.27 .90- \\
01.29 .01 \\
05.29 .23 \text { - } \\
05.40 .40\end{array}$ & & $\begin{array}{l}\text { P-1 leans towards the boy sitting } \\
\text { across him, but he receives no } \\
\text { response and returns to his ini- } \\
\text { tial position. } \\
\text { One boy examines the material } \\
\text { for the task, shows and discusses } \\
\text { it with P-2 only. Others do not } \\
\text { participate. }\end{array}$ \\
\hline $\begin{array}{l}\text { Leadership } \\
\text { (responsibil- } \\
\text { ity): } \\
\text { job distribution; } \\
\text { providing help; }\end{array}$ & $\begin{array}{l}\text { 02.04.93- } \\
02.23 .17\end{array}$ & & $\begin{array}{l}\text { P-2 completes the task with the } \\
\text { boy sitting next to him, and then } \\
\text { get up to present. } \\
\text { Two boys confer regarding all } \\
\text { the task components; others are } \\
\text { less active - all work individu- } \\
\text { ally. }\end{array}$ \\
\hline $\begin{array}{l}\text { Leadership } \\
\text { (manage- } \\
\text { ment): } \\
\text { monitoring the } \\
\text { work of others; } \\
\text { directing oth- } \\
\text { ers towards the } \\
\text { result; } \\
\text { providing op- } \\
\text { portunities for } \\
\text { others; }\end{array}$ & $\begin{array}{l}01.21 .40- \\
01.22 .63 \\
01.22 .63 \text { - } \\
01.23 .17 \\
01.23 .17- \\
01.25 .43\end{array}$ & & $\begin{array}{l}\text { No instances were observed in } \\
\text { the target group. } \\
\text { In another group, there is some } \\
\text { negative interaction due to the } \\
\text { leader's actions: } \\
\text { - A group member wants to } \\
\text { interact and reaches for the } \\
\text { syllable cards that have to be } \\
\text { arranged into words. } \\
\text { The group leader immedi- } \\
\text { ately enfolds the cards and } \\
\text { pulls them towards herself. } \\
\text { The boy pulls back his hand, } \\
\text { leans his head on his hand } \\
\text { and no longer participates. }\end{array}$ \\
\hline
\end{tabular}


chosen pupils revealed that they understood the most important aspects of cooperation: interpersonal connection, help, and joint responsibility. When asked why they like working in a group, they responded:

P-1: Someone can explain things to you; you don't have to do everything, write everything by yourself. Your friends can help you.

P-2: Because then we do everything faster and we can agree faster.

P-3: You are not the only one doing everything since someone helps, and well, there is responsibility because it's not all on you, but on others too. You are not alone.

When asked what helped them the most, they named specific pupils and did not generalise:

P-1: 1-Akvile and Rüta helped, but Julius did too when we had to write about Jablonskis; Rüta gave me information, and Akvile helped me do the work.

P-2: Rüta and Julius helped me, too.

P-3: Rüta helped us most because she was most prepared, she had found the most information.

Teacher A was pleased with the pupils' work and stressed that, when working in groups, the children need to know how to discuss, make reasoned conclusions and to deliver them publicly and forcefully. She considered the lesson a success because children were able to find agreement. Clearly, Teacher A regularly employs group work, and her pupils know the rules and are used to working in groups. They interact and reflect on their performance in the group.

The analysis of Lesson 2 data showed that the lesson content was more prominent than the aspects of cooperative learning. There was little promotive interaction, as shown in Table 3.

Information on the observation form confirms that P-1 only talked to P-3, while P-2 worked and talked only to his neighbour. The video data shows no discernible promotive interaction. There was some sharing of task related materials. There was some pair interaction, but not among the entire team. There was negative interaction that arose from a competitive situation. This was in stark contrast with all the hands that went up in response to the question, 'Who worked well in the group?'

During the pupil interview after the lesson, we asked what had helped to work in the group. The responses showed that students were much less aware of the aspects needed for cooperation:

P-1: 1-because I had a handout [information prepared by classmates]. There was nothing on Jablonskis, but I found something about Basanavičius. Rugile helped [...] when I needed to write.

P-2: Linas helped; well--not really helped. He showed me the sheet about Basanavičius.

P-3: Nikita helped when I asked about something, then he would tell me [.... He seems to be the smartest.

Teacher B revealed that group work and cooperative learning had not been used in this class before the project. She said that they had been doing this for a month, because it had to be done for the project. Data from other sources con- 
firmed that the pupils in this class are not accustomed to working in groups. The complexities of cooperative learning are obviously not something that we should expect a teacher to master in such a short time. Professional development in this area will be dependent on her belief in the value of the method. During her reflections on the lesson, she mostly spoke about her own role, i.e., how she prepared for the lesson, the changes in content, and the scope that she initiated. She said little about pupil learning and cooperation.

\section{INDIVIDUAL AND GROUP ACCOUNTABILITY}

This aspect of cooperative learning is another area in which our research partners had insufficient familiarity with the principles that govern the method. We should not evaluate pupils based on group results. The process of learning can take place within the group, and team members should ensure that each of them has mastered the material. However, at the end of the process, each pupil should be individually assessed and presented with the results. 'Students learn together, but perform alone' (SERC, 2020) is often used as a mantra in cooperative learning. While a lesson should clearly enable students to decide whether the group has achieved the goals, it should also ensure individual success.

Individual accountability is deemed important to prevent instances of what has been called 'social loafing,' 'free riding' or 'hitch-hiking' on the work of others (Laal, Geranpaye \& Daemi, 2013). Learning in groups makes each member a stronger individual. Johnson, Johnson and Holubed (1998) cite L. Vytotsky who stated, 'What children can do together today, they can do alone tomorrow' (p. 1:12).

Reacting to common mistakes encountered in CL practices, Laal, Gernpaye and Daemi (2013) state: '[Cooperative learning] is not to make learners converse with each other, either face-to-face or in a computer conference, while they do their individual assignments. It is not asking students to do the task individually and then asking those who finish first help those who have not yet finished. And it is certainly not having one or a few students do all the work, while the others just add their names to the report' (p. 3).

While shortcomings around positive interdependence can be assigned to truncated professional development on cooperative learning, this is not necessarily the case regarding individual accountability. Participants were repeatedly told that group results should not transfer to individual grades. The participating teachers clearly understood this. However, our limited study uses observational data from a single class period. It is entirely possible that the teachers meant to focus on accountability in a future lesson. Follow-up lesson plans were not a requirement of the DICO+ project, so this is simply a conjecture. We can, however, convincingly state that attempts at the kind of accountability described here were not seen in the two lessons we studied. 
Interpersonal and small group social skills

All theorists and practitioners of cooperative learning stress the importance of specifying and teaching desired behaviour. 'Placing socially unskilled students in a group and telling them to cooperate does not guarantee that they are able to do so effectively. We are not born instinctively knowing how to interact effectively with others. Interpersonal and small group skills do not magically appear when they are needed. You must teach students the social skills required for high quality cooperation and motivate students to use the skills if cooperative groups are to be productive' (Johnson, Johnson \& Holubec, 1994, p. 9:1).

Teachers who participated in the professional development seminars were explicitly told, that if they are not willing to use classroom time to teach teamwork skills, they should forget about successfully employing cooperative learning as a holistic system of learning. The chaos resulting from unprepared classroom interactions is one of the main reasons why teachers reject cooperative learning. Firstly, we must make sure that pupils see the need for teamwork skills. Using role play to provide examples of situations when the skill is missing is one way to do this. Secondly, the students need to understand what the skills are, how to engage in the skill and when to use it. Johnson, Johnson and Holubec (1994) propose the use of T-Charts. As previously mentioned, after listing the skills, the teacher might ask the class 'What would this skill look like?' After brainstorming, the class might agree on a list of nonverbal behaviours that encourage participation: smiles, eye contact, thumbs up, a pat on the back. After students generate several ideas, the teacher might ask the class, 'What would this skill sound like?' The pupils should come up with actual phrases, such as 'What is your idea?', 'Awesome!', 'Good idea!' or 'That's interesting'. These could be posted in the classroom as visual reminders. Thirdly, teachers need to set up practice situations and encourage mastery of the skill (p. 9:3-9:4).

We can only presume that teachers heeded the warning and made use of the activities that would help develop teamwork skills before they engaged in planning the target lesson. We did not expect to see many explicit examples of team skill instruction during the observed lesson, since that should have occurred earlier. However, teamwork skill does not end with the preparatory stage. Johnson, Johnson and Holubec (1994) continue with a fourth step: ensuring that students receive feedback on the use of the skill and that they reflect on how to engage in the skill more effectively next time. We did expect to find some examples of such feedback. Tables 4 presents a few examples of the teacher's role in fostering social skills during Lesson 1. 
Table 4

Examples of the teacher's input in fostering teamwork skills during Lesson 1

\begin{tabular}{|c|c|c|c|}
\hline Episodes & Duration & Evidence & Comments \\
\hline $\begin{array}{l}\text { The } \\
\text { teacher's } \\
\text { role in } \\
\text { fostering } \\
\text { pupils' } \\
\text { teamwork } \\
\text { and social } \\
\text { skills. }\end{array}$ & $\begin{array}{l}10.38- \\
10.43\end{array}$ & & $\begin{array}{l}\text { The teacher approaches the } \\
\text { group and offers advice: If you } \\
\text { cannot think of a fact on your } \\
\text { own, ask a teammate for help. } \\
\text { When the teacher asks how } \\
\text { they did in the group, the } \\
\text { pupils respond in unison: very } \\
\text { well. She then asks a more } \\
\text { specific question regarding } \\
\text { how good they have been at } \\
\text { sharing jobs, and the group } \\
\text { leader acknowledges that they } \\
\text { have done so-so. However, she } \\
\text { places the blame on P-1 who } \\
\text { has not helped sufficiently, in } \\
\text { her estimation. Unfortunately, } \\
\text { the teacher does not offer } \\
\text { feedback to correct this; } \\
\text { possibly because this was a } \\
\text { structural problem, rather than } \\
\text { a social skills problem. }\end{array}$ \\
\hline
\end{tabular}

As previously mentioned, the demonstration of social skills (including teacher's feedback) is less evident in Lesson 2. Although it is obvious that one member of the team was doing most of the work, while others were passively observing or rocking back and forth on their chair, there was little intervention from Teacher B. She occasionally urged all team members to look for information.

\section{GROUP PROCESSING}

Group members need to periodically reflect on their actions, to analyse how well their learning groups are functioning, and to make plans for improvement. Group processing involves both 'taskwork' (related to content) and teamwork. Discussions should revolve around the useful and unhelpful actions of members and should lead to decisions about which actions should be continued or changed. (Johnson \& Johnson, 2008b).

Yager, Johnson, Johnson and Snider (1986) studied the effects of: (a) cooperation that included discussion on how well their group worked and how they could improve effectiveness; (b) cooperation without group reflection, and (c) individual efforts in groups. Results showed that low, medium, and high achievement participants who had worked in cooperative groups that included reflection all attained better daily results than those who did not engage in reflection or worked individually. Cros (2006) also stresses the importance of 
social and individual support when reflecting upon group work. Cros, Lafortune and Morisse (2009) and Morisse, Lafortune and Cros (2011) stress the importance of conveying reflections orally. Reflection is an excellent cognitive tool enabling development of ideas and the search for meaning.

Teacher A devoted a considerable amount of time for reflection on teamwork. This is presented in Table 5. Pupils also filled out written self-assessment forms and rated themselves by colour coding their actions in each task. Green stood for well done, yellow acknowledged that not everything was accomplished, and red - it was not done.

\section{Table 5}

Evidence of reflection on teamwork during Lesson 1

\begin{tabular}{|l|l|l|l|}
\hline Episodes & Duration & Evidence & Comments \\
\hline $\begin{array}{l}\text { Seeking } \\
\text { answers to } \\
\text { questions: } \\
\text { what did we } \\
\text { accomplish? }\end{array}$ & 12.40 .10 - & & $\begin{array}{l}\text { The group leader asks each } \\
\text { group member their opinion } \\
\text { about how successfully they } \\
\text { hat else } \\
\text { should we accomplished task } 1 . \text { The } \\
\text { do? How } \\
\text { can we } \\
\text { do that } \\
\text { differently? }\end{array}$
\end{tabular}

During the interview P-2 stated that he enjoyed everything because he liked teamwork. Group leader P-3 recognised the importance of not doing things alone because then the responsibility does not fall on one person. P-1 and P-3 acknowledged that there were quarrels, and the teacher devoted time to discuss how disagreements can lead to agreement. P-1 also noted that group work is not as effective when pupils come to class unprepared, which is also stressed by Desparois and Lambert (2014) and by Hasni, Belletête and Potvin (2018). Noise was also an issue for P-1. In general, the pupils in Lesson 1 were very positive about cooperative group work and acknowledged the importance of giving and receiving respect. Although time was devoted to reflection, there was a lack of deeper meta-reflection on group work.

As mentioned previously, both teachers ran out of time for more complete processing of their work in groups. In both cases (more so in Lesson 2) the teachers reflected on the taskwork and the lesson plan rather than the teamwork and social skills. Teacher B devoted almost no time to this element of cooperative learning, and it was apparent that she did not find this to be a worthwhile activity. She posed a general question to the entire class and not all groups responded. Before the lesson, the teacher distributed the self-assess- 
ment forms and instructed the pupils to fill them out after the first task. She also told them not to use their red markers, since there were no observers in the class at this time. There was no discussion about the self-assessment form, the children were not asked to share, and the teacher posed no questions about cooperation. All her questions centred around the completion of the task. In her own reflection, she spoke mostly about herself, lesson preparation, changes in lesson content, and lesson scope, rather than focusing on pupil learning or cooperation.

\section{CONCLUSIONS}

Cooperative learning is more than pupils working together. It requires teachers to consciously pick structures that compel students to use social skills and become interdependent with one another to complete a job. Five key elements have been identified as essential for cooperative learning to be effective: (a) positive interdependence, (b) face-to-face promotive interaction, (c) individual and group accountability, (d) interpersonal and small group social skills, (e) group processing. Although the scope of the research was limited to two classes in a single primary school, it became apparent that the teachers' attitudes and experience with group work strongly influenced how they interpreted these five elements. While face-to-face promotive interaction was the strongest factor, there were almost no signs of positive interdependence and individual accountability.

This study underlines the importance of 'in situ' research in the classroom. Although we are professional researchers and have had multiple opportunities to observe work in classrooms, we did not readily perceive many of the issues that might undercut a more fulfilling experience of cooperative learning. Constantly going backwards and forwards between theories of cooperative learning and the collected data, we were able to understand many of the challenges, misunderstandings, and misperceptions that surround this very popular method. The study revealed which elements of cooperative learning need to be stressed in teacher pre-service and in-service settings.

The findings also allow us to focus our future research on cooperative learning, both within and outside the framework of the DICO+ project. When lessons resume after the COVID-19 pandemic lockdown, we will be able to offer much more targeted professional development opportunities for teachers, based on the findings of this and future research.

As the DICO+ project continues, it will be interesting to see whether the other 7 countries have encountered similar strengths and weaknesses, or whether different learning contexts yield different results.

Note: The research was funded, in part, by the Erasmus+ project DICO+: 'Inclusive cooperation devices' (Dispositifs Inclusifs de Coopération). 


\section{REFERENCES}

[1] Altet, M. (2009a). Des tensions entre professionnalisation et universitarisation em formation d'enseignants à leurs articulation: curriculum et transations nécessaires. In Etienne, R., Altet, M., Lessard, C., Paquay, L. \& Perrenoud, P. (Eds.). L'université peut-elle vraiment former les enseignants? (pp. 215-232). Bruxelles: De Boeck,

[2] Altet, M. (2009b). De la psychopédagogie à l'analyse plurielle des pratiques. In 40 ans des sciences de l'éducation: L'âge de la maturité? Questions vives. Caen: Presses Universitaires de Caen, 31-48.

[3] Altet M. (2017). L'observation des pratiques enseignantes effectives en classe: recherche et formation. Cadernos de Pesquisa, 47(166), 1196-1223.

[4] Altet, M., Bru, M., \& Blanchard-Laville, C. (2012). Observer les pratiques enseignantes: pour quels enjeux? Paris: L'Harmattan.

[5] Augustine, D. K., Gruber, K. D., \& Hanson, L. R. (1989-1990). Cooperation works! Educational Leadership, 47, 4-7.

[6] Bressoux, P. (2012). L'influence des pratiques enseignantes sur les acquisitions scolaires desélèves. Regards croisés sur l'économie, 12, 208-217.

[7] Buchs, C. (2017). Comment organiser l'apprentissage des élèves par petits groupes? In Différenciation pédagogique: comment adapter l'enseignement pour la réussite de tous les élèves? Paris: Conseil National d'évaluation du Système Scolaire. https:/ / archive-ouverte.unige.ch/ unige:95551

[8] Clanet, J. (2009). (Dir.). Recherche/formation des enseignants, quelles articulations? Rennes: PUR.

[9] Creswell, J. W. (2007). Qualitative inquiry \& research design: Choosing among five approaches (2 ${ }^{\text {nd }}$ ed.). NY: Sage Publications.

[10] Cros, F. (2006). Écrire sur sa pratique pour développer des compétences professionnelles. Paris: L'Harmattan.

[11] Cros, F., Lafortune, L., \& Morisse, M. (2009). Écritures en situations professionnelles. Québec: Presses de l'Université du Québec.

[12] Davidson, N., \& Major, C. H. (2014). Boundary crossings: Cooperative learning, collaborative learning, and problem-based learning. Journal on Excellence in College Teaching, 25(3\&4), 7-55.

[13] Desparois, A., \& Lambert, C. (2014). La vidéo au service des apprentissages. Impact sur la motivation et la réussite des étudiants. Canada: Collège André-Grasset.

[14] DICO+. (2019). Dispositifs Inclusifs de Coopération http:/ / dicoplus.eu/projet-Royaume-Uni.html

[15] Doig, B., \& Groves, S. (2011). Japanese lesson study: teacher professional development through communities of inquiry, Mathematics teacher education and development, 13(1), 77-93.

[16] Durand, M., Ria, L., \& Veyrunes, P. (2010). Analyse du travail et formation: un programme de recherche empirique et technologique portant sur la signification et l'organisation de l'activitée des enseignants. In F. Yvon \& F. Saussez. Analyser l'activitée enseignante: des outils méthodologiques et theoriques pour l'intervention et la formation (pp. 17-40). Presses de l'Université de Laval.

[17] Gillies, R. M., \& Adrian, F. (2003). Cooperative Learning: The social and intellectual Outcomes of Learning in Groups. London: Farmer Press.

[18] Gillies, R. (2004). The effects of cooperative learning on junior high school students during small group learning. Learning and Instruction, 14, 197-213. http://dx.doi.org/10.1016/ S0959-4752(03)00068-9

[19] Gillies, R. (2008). The effects of cooperative learning on junior high school students' behaviours, discourse, and learning during a science-based learning activity. School Psychology International, 29, 328-347.

[20] Gillies, R. M. (2016). Cooperative learning: Review of research and practice. Australian Journal of Teacher Education, 41(3). http:/ / dx.doi.org/10.14221/ajte.2016v41n3.3.

[21] Hasni, A., Belletête, V., \& Potvin, P. (2018). Les démarches d'investigation scientifique à l'école. Un outil de réflexion sur les pratiques de classe. Québec: Université de Sherbrooke.

[22] Hattie, J. (2009). Visible Learning: A Synthesis of Over 800 Meta-Analyses Relating to Achievement. London: Routledge.

[23] Hmelo-Silver, C. E., Kati, E., Nagarajan, A., \& Chernobilsky, E. (2007). Soft Leaders, hard artifacts, and the groups we rarely see: Using video to understand peer learning processes. In R. Goldman, R. Pea, R. B. Barron \& S. J. Derry, Video Research in the Learning Sciences. New York: Routledge, 55-270.

[24] Johnson, D., \& Johnson, R. (1975). Learning together and alone, cooperation, competition, and individualization. Englewood Cliffs, NJ: Prentice-Hall. Johnson, 
[25] Johnson, D., W., \& Johnson, R. T. (1990). Cooperative learning and achievement. In S. Sharan (Ed.), Cooperative learning: Theory and research (pp. 23-37). New York: Praeger.

[26] Johnson, D., \& Johnson, R. (1994). Learning together and alone, cooperative, competitive, and individualistic learning. Needham Heights, MA: Prentice-Hall.

[27] Johnson, D. W., \& Johnson, R. T. (1999). Learning together and alone: cooperative, competitive, and individualistic learning. Boston: Allyn and Bacon.

[28] Johnson, D., W., \& Johnson, R. T. (2003). Student motivation in cooperative groups: Social interdependence theory. In R. Gillies \& A. Ashman (Eds.), Cooperative learning: The social and intellectual outcomes of learning in groups (pp. 136-176). London: Routledge Falmer.

[29] Johnson, D. W., \& Johnson, R. T. (2005). New developments in social interdependence theory. Genetic, Social, and General Psychology Monographs, 131(4), 285-358.

[30] Johnson, R. T., \& Johnson, D. W. (2008a). Active learning: Cooperation in the classroom. The Annual Report of Educational Psychology in Japan, 47, 29-30.

[31] Johnson, D. W., \& Johnson, R. T. (2008b). Social interdependence theory and cooperative learning. In Gillies, R. M., Ashman, A. F. \& Terwel J. (Eds.), The Teacher's Role in Implementing Cooperative Learning in the Classroom (pp. 9-38). New York: Springer.

[32] Johnson, D. W., \& Johnson, R. T. (2019). Cooperative learning: The foundation for active learning. In S. M. Brito (Ed.), Active learning - beyond the future, IntechOpen, DOI: 10.5772/intechopen.81086. https://www.intechopen.com/books/active-learning-beyond-the-future/ cooperative-learning-the-foundation-for-active-learning

[33] Johnson, D. W., Johnson, R. T., \& Holubec, E. J. (1994). The nuts and bolts of cooperative learning. Edina $\mathrm{MN}$ : Interaction Book Company.

[34] Johnson, D. W., Johnson, R.T., \& Holubec, E. J. (1998). Cooperation in the classroom. Boston, MA: Allyn \& Bacon.

[35] Kagan, S. (1994). Cooperative learning. San Clemente, CA: Kagan Publications.

[36] Kagan, S. (2013). Kagan Cooperative Learning Structures. San Clemente, CA: Kagan Publishing.

[37] Kagan, S., \& Kagan M. (2009). Kagan Cooperative Learning. San Clemente, CA: Kagan Publishing.

[38] Kohn, A. (1992). No contest-The case against competition: Why we lose in our race to win. (Rev. ed.). Boston: Houghton Mifflin

[39] Laal, M., Geranpaye, L., \& Daemi, M. (2013). Individual accountability in collaborative learning. Procedia - Social and Behavioral Sciences, 93, 286-289.

[40] Morisse, M., Lafortune, L., \& Cros, F. (Eds.) (2011). Se professionnaliser par l'écriture. Quels accompagnements? Québec: Presses de l'Université du Québec.

[41] OECD. (2018). The future of education and skills: Education 2030. Paris: OECD. https://www.oecd. org/education/2030/E2030\%20Position\%20Paper\%20(05.04.2018).pdf

[42] May, M., \& Doob, L. (1937). Cooperation and competition. New York: Social Sciences Research Council.

[43] Panitz, T. (1999). Collaborative versus cooperative learning: A comparison of the two concepts which will help us understand the underlying nature of interactive learning (ED448443). ERIC. https:/ / files.eric. ed.gov/fulltext/ED448443.pdf

[44] SERC. (2020). What is cooperative learning? Carleton College: Science Education Resource Center. https://serc.carleton.edu/serc/terms_of_use.html

[45] Slavin, R. E. (1990). Cooperative learning. New Jersey: Prentice-Hall.

[46] Slavin, R. E. (1994). A practical guide to cooperative learning. Boston: Allyn \& Bacon.

[47] Slavin, R. E. (1995). Cooperative learning: Theory, research, and practice (2nd ed.). Englewood Cliffs, NJ: Prentice Hall.

[48] Stake, R. E. (2006). Multiple case study analysis. New York: The Guilford Press.

[49] Talbot, L., \& Bru, M. (2007). Des compétences pour enseigner: entre objets sociaux et objets de recherche. Rennes: PUR

[50] Verhoeven, M. (2010). Traitement scolaire de la différence culturelle et identités de jeunes issus de l'immigration. Une recherche semi-inductive et comparative multi-niveaux. In L. Paquay, M. Crahay \& J. M. De Ketele (Eds.), L'analyse qualitative en éducation: Des pratiques de recherche aux critères de qualité (pp. 87-111). Bruxelles: Editions De Boeck Université.

[51] Yager, S., Johnson, R., Johnson, D. W., \& Snider, B. (1986). The impact of group processing on achievement in cooperative learning groups. Journal of Social Psychology, 126, 389-397.

[52] Yin, R. K. (2018). Case study research and applications: Design and methods (6th ed.). Thousand Oaks, CA: Sage Publications. 